\title{
Basin Morphometry of Bunbuni River, Chotanagpur Plateau, In India
}

\author{
Sumitra Mandi ${ }^{1}$, Kalicharan Soren ${ }^{2}$ \\ ${ }^{1}$ Assistant Teacher, Birendranagar High School, Hooghly - 712102 (W.B.) India \\ ${ }^{2}$ Lab.Attendent, School of Water Resource Engg. Jadavpur University Kol -700032(W.B.) India
}

\begin{abstract}
Morphometric analysis is refers as the quantitative assessment of appearance distinctiveness of the terrain surface and any landform unit. This is the most common procedure in basin analysis, as morphometry form an ideal areal unit for interpretation and analysis of fluvially originated landforms The Bunbuni river basin is a sub - basin of the mighty River Kiur which is situated in parts of Giridih \& Munger districts of Jharkhand and Bihar. Total area of the study area is $58.75 \mathrm{Km}^{2}$. In the study area shows sub dendritic to dendritic drainage pattern. The watershed was classified as 5th order drainage basin. Different methods of morphometric analysis have been adopted here which covers the linear, areal, and relief aspects as a whole. The drainage density (Dd) of the basin is $1.89 \mathrm{~km}-1$ the stream frequency of the basin is 2.94 .
\end{abstract}

Keywords: Morphometric analysis, Drainage density, Stream frequency, dendritic drainage pattern, Bunbuni river basin

\section{Introduction}

Morphometry is a fundamental resource in geomorphic analysis of study area. Morphometry is distinct as the dimension and statistical analysis of the pattern of the earth's surface and of the shape and dimension of its landforms [1]. This is the most common technique in basin analysis, as morphometry form an ideal areal unit for interpretation and analysis of fluvially originated landforms The increase of population has been creating more and more difficulty on agriculture sector for rising the food grain production, which accordingly enlarged deforestation and require for more water. About $70 \%$ of population in India is reliant on agriculture, directly or indirectly. India has diverse geographical features and diverse climates. Drainage basins or basins should be the study area for the improved perceptive of the hydrologic system. The most favorable and sustainable development of the resource is precondition so that it is assessed realistically to avoid any future problems as regards its qualitative and quantitative availability. As a result, the significance of water has been accepted and greater importance is being laid on its economic use and better management. The basin morphometric characteristics of the various basins have been studied by many scientists using conventional (Horton, 1945; Smith, 1950; Strahler, 1957) and remote sensing, GIS, and GPS has useful tools to defeat most of the problems of land and water resources planning and management on the account of usage of conventional methods of data process.

\section{Location of the Study Area}

The Bunbuni river basin bordered between latitude $24^{\circ} 39^{\prime} 45^{\prime \prime} \mathrm{N}$ to $24^{\circ} 45^{\prime} 05^{\prime \prime} \mathrm{N}$ and longitude $86^{\circ} 6^{\prime} 55^{\prime \prime} \mathrm{E}$ to $86^{\circ} 10^{\prime} 01^{\prime \prime} \mathrm{E}$ in Survey of India Toposheet numbers $72 \mathrm{~L} / 2$ and having area of about $58.75 \mathrm{~km}^{2}$ ( Fig. 1). The Bunbuni river is one of the tributary of the Bhoriwajor River and Bhoriwajor river is a tributary of river Kiur. This study area has a striking climate. For five to six months of the year, from October onward the days are bright and stimulating. The mean temperature in December is $23{ }^{\circ} \mathrm{C}\left(73^{\circ} \mathrm{F}\right)$.

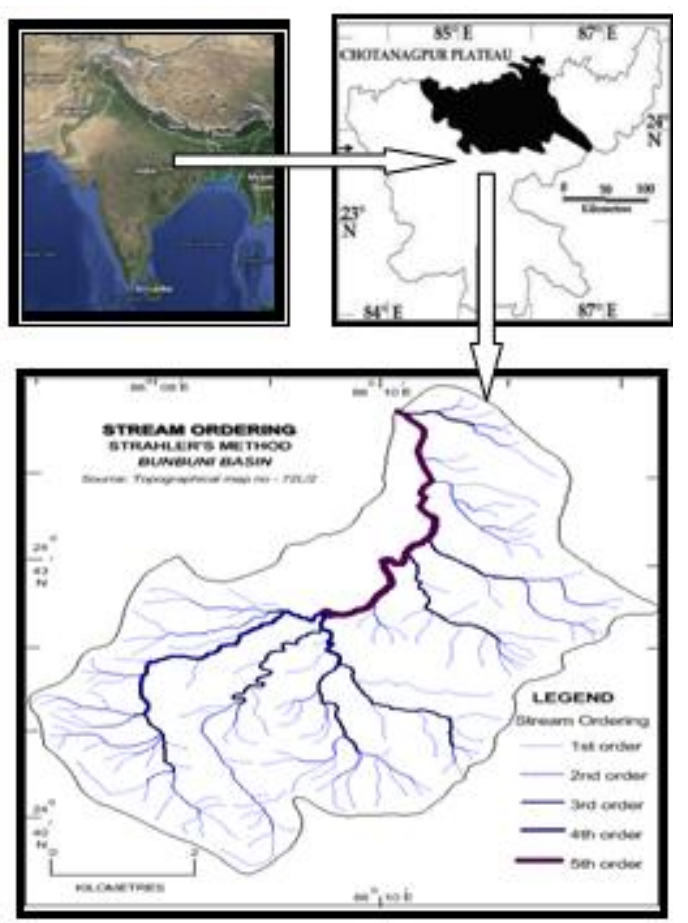

Figure 1: Location map of the study area

The nights are cool and temperatures in winter may drop below freezing point in many places. In April and May the day temperature may cross $38^{\circ} \mathrm{C}\left(100^{\circ} \mathrm{F}\right)$ but it is extremely dry and no humid as in the adjoining plains. The rainy season (June to September) is pleasurable. The study area receives a yearly average rainfall of around 1,400 millimeters (55 in), which is less than the rain forested areas of much of India and almost all of it in the monsoon months between June and August. The Bunbuni river basin shows well developed dendritic to sub dendritic type drainage pattern. (Fig. 2). In the present paper the authors had made an attempt to morphometric analysis of Bunbuni river basin.

\section{Volume 5 Issue 7, July 2016}




\section{International Journal of Science and Research (IJSR)}

ISSN (Online): 2319-7064

Index Copernicus Value (2013): 6.14 $\mid$ Impact Factor (2015): 6.391

\section{Methods \& Techniques}

The Survey of India Toposheet numbers $72 \mathrm{~L} / 2$ on the scale of 1: 50,000 were used for the present study. The morphometric parameters for the delineated basin area were calculated based on formulas suggested by various workers $[2][4][5][6]$. The various morphometric parameters such as linear aspect, aerial aspect and relief aspect of the drainage network: Stream order( $\mathrm{Nu})$, bifurcation ratio( $\mathrm{Rb})$,stream length $(\mathrm{Lu})$, Mean stream length(Lsm), stream length ratio $(\mathrm{RL})$, mean bifurcation ratio(Rbm), Drainage density (Dd), stream frequency (Fs), drainage texture(Rt),elongation ratio(Re), circularity ratio(Rc),form factor(Rf), lemniscate(k), compactness constant $(\mathrm{Cc})$, constant of channel maintenance $(\mathrm{Ccm})$, infiltration number(If), basin Relief (H), Relief ratio((Rh) were computed.

\section{Results and Discussions}

In the present study, morphometric parameters of the Bunbuni basin were determined and their results are summarized in Table 1.

\subsection{Linear Morphometric Aspects}

\subsubsection{Stream Order $(\mathrm{Nu})$}

In the drainage basin analysis the primary step is to find out the stream orders and is based on a hierarchic position of streams. In the current study, the stream segments of the drainage basin have been ranked according to Strahler's stream ordering method. he smallest fingertip tributaries are chosen as 1st order, where two first-order stream join, a channel segment of 2 nd order is created ; where two segment of $2^{\text {nd }}$ order join, a segment of $3^{\text {rd }}$ order is created ; and so on[4]. The stem stream through which all discharged of water and sediment passes is therefore the stream segment of the highest order. The study area belongs to the 5th order drainage basin(fig 2). The total number of 173 streams were recognized out of which 134 are 1 st order, 28 are 2 nd order, 08 are 3 rd order, 02 is representing 4 th order and 1 is $5^{\text {th }}$ order stream. Drainage pattern of the basin has been observed as generally dendritic in the study area, which specifies the homogeneity in texture and lack of structural control.

\subsubsection{Bifurcation Ratio ( $R \mathbf{b})$}

The term bifurcation ratio $(\mathrm{Rb})$ is used to communicate the ratio of the number of streams of any prearranged order to the number of streams in next higher order (Schumn, 1956). Bifurcation ratios normally range between 3.0 and 5.0 for basins in which reveals the geologic structures do not distort the drainage pattern [4]. Strahler established that bifurcation ratio shows a small range of dissimilarity for different regions or for diverse situation dominates. The mean bifurcation ratio value is 2.85 for the study area (Table 1) which indicates that the geological structures are disturbing the drainage pattern.

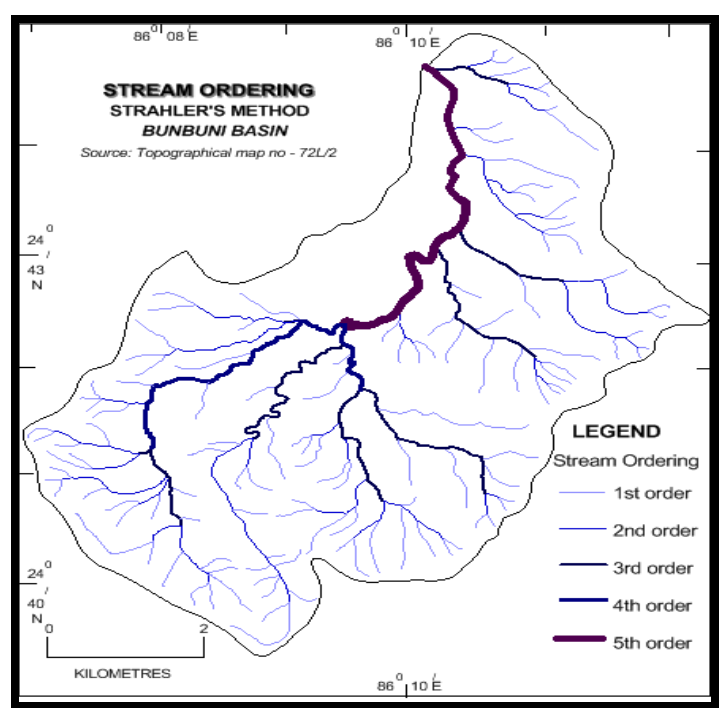

Figure 2: Stream Ordering of Daluaghat Drainage Basin (Source: SOI Topographical Map 72L/2)

\subsubsection{Stream Length $(\mathrm{Lu})$}

The length of the stream channel is a dimensional asset, which indicates the size of the element of drainage lines. It is the total length of stream in an exacting order. It is the most important hydrological characteristic of the basin as it reveals surface runoff behavior. Stream of comparatively smaller length is individuality of areas with larger slopes and finer texture. Normally, the total length of the stream segment is maximum in first order streams and decreases as the stream order increases. The numbers of

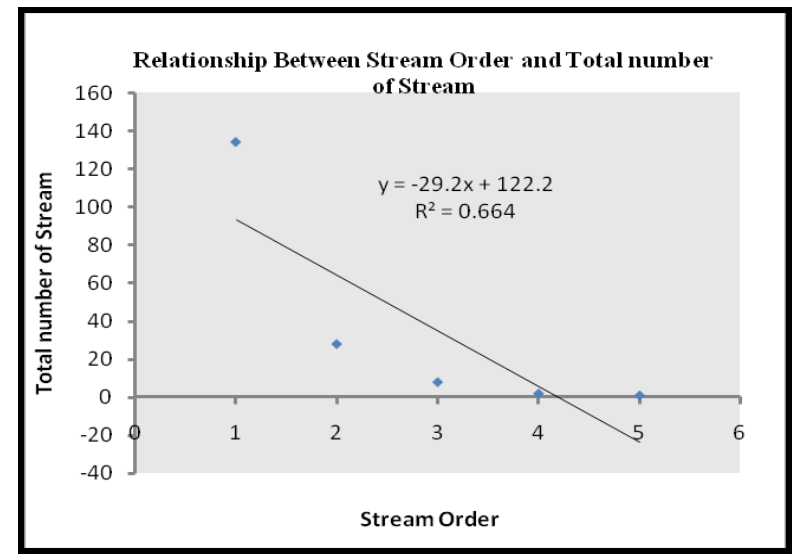

Figure 3: Relationships between Stream Order and Stream Numbers $(\mathrm{Nu})$

stream of different orders in a basin were counted and their lengths are calculated with the assist of the software. Correlation between number of streams opposed to stream order and length of stream opposed to stream order were measured (fig 3 and 4) and calculated in Table 1. It showed the linear pattern which indicates the homogenous rock material subjected to weathering erosion characteristics of the basin. Variation from its common performance indicates that the terrain is characterized by disparity in lithology and topography.

\subsubsection{Length of Overland Flow (Lo)}

Lo is one of the most significant self-determining variables disturbing both hydrologic and physiographic development 


\section{International Journal of Science and Research (IJSR) \\ ISSN (Online): 2319-7064 \\ Index Copernicus Value (2013): 6.14 | Impact Factor (2015): 6.391}

of drainage basins and relates reciprocally to the average slope of the channel and is moderately synonymous with the length of sheet flow to a large extent. The length of overland flow depends mainly on the degree of relief disintegration, and hence on the drainage density. In this study, the length of overland flow of the Bunbuni drainage basin is 0.26 , which covey low surface runoff in the present study area.

Table 1: Linear aspects of the drainage network of the study area

\begin{tabular}{|c|c|c|c|c|c|c|}
\hline Stream order & $\begin{array}{c}\text { Number of } \\
\text { Stream }(N u)\end{array}$ & $\begin{array}{c}\text { Total Stream } \\
\text { Length in } \mathrm{Km}(\mathrm{Lu})\end{array}$ & $\begin{array}{c}\text { Mean } \\
\text { Stream } \\
\text { Lengths }\end{array}$ & $\begin{array}{l}\text { Stream Length } \\
\quad \text { Ratio (Rl) }\end{array}$ & $\log N u$ & $\log L u$ \\
\hline $1^{\text {st }}$ & 134 & 61.64 & 0.46 & & 2.13 & 1.78 \\
\hline $2^{\text {nd }}$ & 28 & 23.2 & 0.83 & 1.8 & 1.44 & 1.36 \\
\hline $3^{\text {rd }}$ & 8 & 15.7 & 1.96 & 2.36 & 0.903 & 1.19 \\
\hline $4^{\text {th }}$ & 2 & 5.19 & 2.59 & 1.32 & 0.301 & 0.72 \\
\hline 5 th & 1 & 5.55 & 5.55 & 2.14 & 0 & 0.74 \\
\hline Total & 173 & 111.28 & 0.64 & & & \multirow{3}{*}{$\begin{array}{c}\text { Mean Bifurcation } \\
\text { Ratio }\end{array}$} \\
\hline \multicolumn{6}{|c|}{ Bifurcation Ratio } & \\
\hline \multicolumn{2}{|c|}{$1^{\text {st }}$ Order $/ 2^{\text {nd }}$ Order } & $2^{\text {nd }}$ Order $/ 3^{\text {rd }}$ Order & \multicolumn{2}{|c|}{$3^{\text {rd }}$ Order $/ 4^{\text {th }}$ Order } & $4^{\text {th }}$ Order $/ 5^{\text {th }}$ Order & \\
\hline \multicolumn{2}{|c|}{4.78} & 3.5 & \multicolumn{2}{|l|}{4} & 2 & 2.85 \\
\hline
\end{tabular}

\subsection{Areal Aspects of the Drainage Basin}

Area of a basin (A) and perimeter (P) are the significant parameters in quantitative morphology. The area of the basin is definite as the total area anticipated ahead a horizontal plane contributing to cumulate of all order of basins. Perimeter is the length of the boundary of the basin which can be drawn from topographical maps. Basin area is hydrologically significant because it straightforwardly affects the size of the storm hydrograph and the magnitudes of peak and mean runoff. It is motivating that the highest flood discharge per unit area is inversely related to size [7]. The aerial aspects of the drainage basin such as drainage density (D), stream frequency (Fs), texture ratio $(\mathrm{T})$, elongation ratio $(\mathrm{Re})$, circularity ratio $(\mathrm{Rc})$ and form factor ratio (Rf) Infiltration Number(If) were calculated and results have been given in Table 2 .

\subsubsection{Basin Area (A)}

Basin area is the straight result of the drainage development in an exacting basin. The area of Bunbuni river basin is about $58.75 \mathrm{~km}^{2}$. This reveals that rainwater will arrive at the main channel more rapidly where the water has much further to travel (Table 2).

\subsubsection{Perimeter $(P)$}

The perimeter is the total length of the drainage basin boundary. The perimeter of the study area is $30.25 \mathrm{~km}$

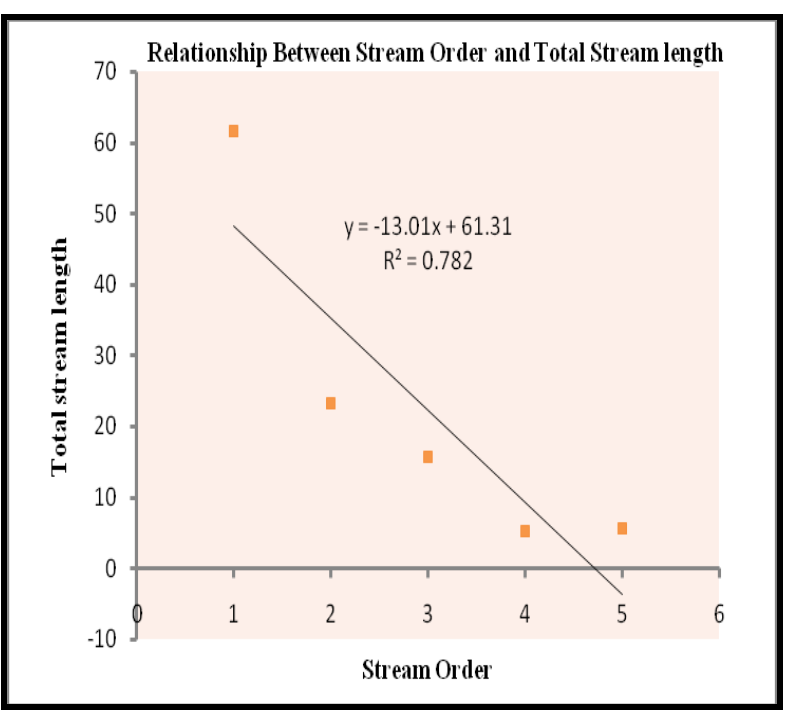

Figure 4: Relationship between Stream Order and Total Stream Length (Lu)

\subsubsection{Drainage density (Dd)}

Drainage density (Dd) represents the convenience of spacing of channels, thus given that a quantitative determine of the average length of stream channel for the entire basin. The total length of the stream of all orders divided by the area of the basin[2]. In general, the low drainage density convey to coarse texture while high drainage density indicates to fine texture [4]. High drainage density is the consequential of weak and impermeable subsurface material and bare vegetation and mountainous relief. The drainage density (Dd) of the basin is $1.89 \mathrm{~km}-1$ (Table 2).

\subsubsection{Stream frequency $(\mathrm{Fs})$}

Stream frequency $(\mathrm{Fs})$ is the total number of stream segments of all orders per unit area [2].The stream frequency of the basin is 2.94. The value of stream frequency (Fs) for the basin display positive relationship with the drainage density value of the area representing the increase in stream population with reverence to amplify in drainage density(Table2). 


\section{International Journal of Science and Research (IJSR) \\ ISSN (Online): 2319-7064 \\ Index Copernicus Value (2013): 6.14 | Impact Factor (2015): 6.391}

\subsubsection{Texture Ratio (Tr)}

Texture ratio $(\mathrm{Tr})$ is a significant aspect in the drainage morphometric analysis which is depending on the underlying lithology, infiltration capacity and relief aspect of the terrain. There has classified drainage texture into 5 different textures i.e., very coarse $(<2)$, coarse ( 2 to 4$)$, moderate (4 to 6 ), fine (6 to 8 ) and very fine $(>8)[8]$. In the present study the texture ratio of the basin is 5.72 and categorized as moderate in nature (Table 2).

\subsubsection{Form Factor Ratio (Rf)}

Form Factor Ratio is the dimensionless ratio of the basin area to the square of basin length [2]. The value of form factor would always be less than 0.754 (for a perfectly circular basin). The Form Factor Ratio value of the Bunbuni river basin is 0.54 (Table 2).

\subsubsection{Elongation Ratio (Re)}

Elongation ratio $(\mathrm{Re})$ as the ratio of diameter of a circle of the same area as the basin to the maximum basin length[5]. It is an extremely noteworthy index in the analysis of basin shape which helps to give an design about the hydrological character of a drainage basin. The value $\mathrm{Re}$ in the present study area was found to be 0.83

\subsubsection{Circularity Ratio (Rc)}

The circularity ratio $(\mathrm{Rc})$ is exaggerated by the lithological character of the basin. The ratio is more influenced by length, frequency (Fs), and gradient of streams of different orders rather than slope conditions and drainage pattern of the basin. The calculated Rc value for the study area is 0.78 respectively (table 2)

\subsubsection{Compactness constant $(\mathrm{Cc})$}

Compactness constant defined as the ratio between the area of the basin and the perimeter of the basin [3]. In present study area, the value of compactness constant is 1.36 (Table 2).

\subsubsection{Constant channel maintenance $(\mathrm{Ccm})$}

Constant channel maintenance is the reciprocal of drainage density as a property termed constant of channel maintenance [5]. It is expressed in sq $\mathrm{Km} / \mathrm{Km}$. since it represents the drainage to maintain one unit channel length, Hence it is a measure of basin erodibility. The value of basin is 3.03 respectively (Table 3 ). It expressed strong lithologic rocks with a surface of high permeability.

Table 2: Aerial and Relief aspects of drainage network of study area.

\begin{tabular}{|c|c|c|c|}
\hline $\begin{array}{c}\text { S. } \\
\text { No }\end{array}$ & Morphometric parameters & Symbol /Formula & Result \\
\hline 1 & Area of the basin $\left(\mathrm{Km}^{2}\right)$ & & 58.75 \\
\hline 2 & Perimeter (Km) & & 30.25 \\
\hline 3 & $\begin{array}{c}\text { Maximum elevation of the } \\
\text { basin (mts) (Max) }\end{array}$ & & 534 \\
\hline 4 & $\begin{array}{c}\text { Minimum elevaition of the } \\
\text { basin (mts) (Min) }\end{array}$ & & 136 \\
\hline 5 & Relief ratio (Rr) & $\mathrm{Rr}=\mathrm{H} / \mathrm{Lb}$ & 38.26 \\
\hline 6 & Relative relief (R) & $\mathrm{R}=\mathrm{Max}-\mathrm{Min}$ & 398 \\
\hline 7 & Dissection index & $\mathrm{R} / \mathrm{Max}$ & 0.74 \\
\hline 8 & Ruggedness index (RI) & $\mathrm{RI}=\mathrm{R} \times \mathrm{Dd}$ & 752.22 \\
\hline
\end{tabular}

\begin{tabular}{|c|c|c|c|}
\hline 9 & Drainage density (Dd) & $\mathrm{Dd}=\mathrm{Lu} / \mathrm{A}$ & 1.89 \\
\hline 10 & Stream frequency $(\mathrm{Fs})$ & $\mathrm{Fs}=\mathrm{Nu} / \mathrm{A}$ & 2.94 \\
\hline 11 & Texture ratio $(\mathrm{Tr})$ & $\mathrm{Nu} / \mathrm{P}$ & 5.72 \\
\hline 12 & Form factor $(\mathrm{Ff})$ & $\mathrm{Ff}=\mathrm{A} / \mathrm{Lb}^{2}$ & 0.54 \\
\hline 13 & Circulatory ratio $(\mathrm{Rc})$ & $\mathrm{Rc}=4 \times \prod \times \mathrm{A} / \mathrm{P}^{2}$ & 0.78 \\
\hline 14 & Elongation ratio $(\mathrm{Re})$ & $\mathrm{Re}=(4 \times \mathrm{A} / \Pi) 0.5 / \mathrm{Lb}$ & 0.83 \\
\hline 15 & Length of the overland flow & $\mathrm{Lo}=1 /(2 \times \mathrm{Dd})$ & 0.26 \\
& $($ Lo) & & \\
\hline 16 & Compactness constant $(\mathrm{Cc})$ & $0.2821 \times \mathrm{P} / \mathrm{A} 0.5$ & 1.12 \\
\hline 17 & Compactness co- efficient & $\mathrm{P} / \mathrm{V} 2 \prod \mathrm{A}$ & 1.57 \\
\hline 18 & Infiltration number & $\mathrm{If}=\mathrm{Dd} \times \mathrm{Fs}$ & 5.55 \\
\hline 19 & Lemniscate ratio & $\mathrm{Lb} / 4 \mathrm{~A}$, & 0.46 \\
\hline
\end{tabular}

Where, $\mathrm{Lu}=$ Total stream length of all orders, $\mathrm{A}=$ Area of the basin, $\mathrm{Km}^{2} . \mathrm{Nu}=$ Total number of streams of all orders, $\mathrm{P}=$ Perimeter of the basin, $\mathrm{Km}$. Lb = basin length, $\mathrm{Km}$. Dd = Drainage density. Fs $=$ Stream frequency

\subsubsection{Lemniscate ratio (K)}

The lemniscate ratio to determine the slope of the basin[7]. In the following equation has been used -

$$
\mathrm{K}=\mathrm{Lb}^{2} / 4 \times \mathrm{A}
$$

Where, $\mathrm{Lb}=$ Square of basin length, $\mathrm{Km}$

$\mathrm{A}=$ Area of the basin, $\mathrm{Km}^{2}$.

The value for the basin is 0.46 respectively (Table 2)

\subsubsection{Infiltration Number (If)}

Infiltration number is determined by multiplying the value of drainage density (Dd) and stream frequency (Fs).It is expressed by formula -

$$
\text { If }=\mathrm{Dd} \times \mathrm{Fs}
$$

Where, $\mathrm{Dd}=$ Drainage density, $\mathrm{Fs}=$ Stream frequency. Thus higher the value of infiltration number greater the permeability of soil covers. In the present basin value are 0.4848 respectively (Table 2 )

\section{Conclusion}

The quantitative investigation of morphometric parameters is constructing to be of huge effectiveness in river basin assessment, watershed prioritization for soil and water preservation, natural resource management at micro level. The morphometric study of Bunbuni river reveals that the basin is fifth order basin. The basin shows dendritic type drainage pattern. Mean length of channel segments of a given order is greater than that of the next lower order but less than that of the next higher order. The logarithm of stream length of each order as a function of order is plotted and relation between stream order and mean stream length yields a set of points insincere generally along a straight line that indicates no strong structural control in the area. The mean bifurcation ratio $(\mathrm{Rbm})$ is 2.85 for the study area (Table 1 ), which indicates that the geological structures are disturbing the drainage pattern. In the present study the texture ratio of the basin is 5.72 and categorized as moderate in nature. The Circularity ratio are 0.78 which indicating that the basin is elongated in shape, low discharge of runoff and highly permeable of the sub soil condition. The elongated basin with low form factor ranges from 0.54 representing them to be elongated in shape and flow for longer period. 


\section{References}

[1] Clarke, J.I (1966), Morphometry from maps, in: Dury, G.H. (Ed), Essays in Geomorphology, American Elsevier Publ. Co., New York, pp 235-274

[2] R.E Horton, Drainage basin characteristics, Trans. Amer. Geophys. U.14, (1932), pp 350-61.

[3] R.E. Horton, "Erosional development of streams and their drainage basins: hydrophysical approach to quantitative morphology", Bull. Geol. Soc. Amer.,5 1945,pp 275-370.

[4] A.N. Strahler, Quantitative geomorphology of drainage basins and channel networks In. Handbook of Applied Hydrology, McGraw Hill Book Company, New York, Section 4II, 1964.

[5] S.A Schumm, The evolution of drainage system and slopes in Badlands at Perth Amboy, New Jersey, Bulletin of Geological Society of America, 67,( 1956) pp 214-236.

[6] V.C.Miller, "A quantitative geomorphic study of drainage basin characteristics in the Clinch Mountain area, Varginia and Tennessee", 1953, Project NR 389042,Tech. Rept.3.,Columbia University, Department of Geology, ONR, Geography Branch, New York.

[7] Chorley,R.J., Donald,E.G., Malm., and Pogorzelski,H.A., "A new standard for estimating drainage basin shape", Amer. Jour. Sci.,255, 1957, pp $138-141$.

[8] K.G. Smith, , "Standards for grading texture of erosional topography", Amer. Jour.Sci.,248, 1950 pp 655- 668

[9] R. J. Chorley, S. A Schumm,. And D.E., Sugden, Geomorphology, Methuen and Co. Ltd., London, (1985), pp 316-326.

[10] S L. Dingman FLUVIAL HYDRAULICS Copyright ( 2009 by Oxford University Press.

[11]D. Knighton. Fluvial forms and processes A new perspective. Arnold publication (1998).

[12]L.B Leopold, M.G Wolman and J.P.Miller, Fluvial processes in geomorphology, Eurasia Publishing House, New Delhi. (1969).

[13] A. Miller, the skin of the earth. Methuen \& Co. Ltd., London (1953).

[14]M. Morisawa, Rivers-forms and process, Longman group, London, (1985), pp 54-56 and 70-73.

[15]P.K Sen., Geomorphological analysis of drainage basins, the University of Burdwan, Burdwan (1993).

[16]R.L Singh, India-a regional geography, National geographical society of India, Varanasi. (2008).

[17] M.A Summerfield, Global geomorphology, Prentice Hall, New Delhi, (1991), pp 208-212.

[18] S. Ghosh. Geomorphic land evaluation for sustainable use of lands resource in Puruliya district, W. B. Journal of landscape systems and ecological studies, 2012(June) vol.35 (1). pp. $263-274$.

[19] N.S Magesh and N. Chandrasekar. and J.Arab GIS model-based morphometric evaluation of Tamiraparani subbasin, Tirunelveli district, Tamil Nadu, India DOI 10.1007/s12517-012-0742- Geosci $z$ (C) Saudi Society for Geosciences 2012. 